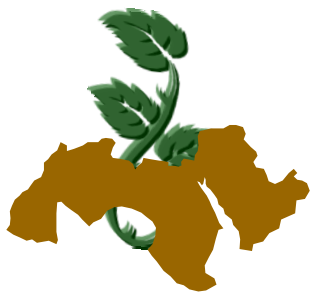

Arab Univ. J. Agric. Sci., Ain Shams Univ., Cairo, 15(2), 371-382, 2007

\title{
EFFECT OF DIETARY ZINC, COPPER AND IRON LEVELS ON SUPEROXIDE DISMUTASE, CATALASE AND GLUTATHIONE-S- TRANSFERASE ACTIVITY
}

\author{
Abeer, M.N.H. El-Dakak'; Mona, H.M. Ahmed'; Dalia, M.M. El-Nahal'1 \\ 1- Special Food and Nutrition Dept., Food Technology Research Institute, Agric. Res. Center, Giza, \\ Egypt
}

Keywords: Zinc, Copper, Iron, Superoxide dismutase, Catalase, Glutathione-s-transferase

\begin{abstract}
The interactions between dietary zinc, copper and iron and their effects on antioxidant enzymes activity [superoxide dismutase (SOD), catalase (CAT) and glutathione S-transferase (GST)] were examined. Fifty-four rats weighting approximately between 80-100 grams were divided into nine groups (E1- E9). Each group containing six rats was fed on basal diet with varying amount of $\mathrm{Zn}$ (2.5, 35 or $175 \mathrm{mg} \mathrm{Zn/kg} \mathrm{diet),} \mathrm{Cu} \mathrm{(1.2,} \mathrm{6.3,} \mathrm{or} 25$ $\mathrm{mg} \mathrm{Cu} / \mathrm{kg} \mathrm{diet})$ and $\mathrm{Fe}(10,50$ or $230 \mathrm{mg} \mathrm{Fe} / \mathrm{kg}$ diet). The second group (E2) was fed a diet deficient in all studied elements $(2.5 \mathrm{mg} \mathrm{Zn}, 1.2 \mathrm{mg} \mathrm{Cu}$, and $10 \mathrm{mg}$ Fe per $1 \mathrm{~kg}$ diet). The results of E2 showed a decrease in SOD and CAT activity and increase GST in plasma erythrocytes and tissues. Moreover, plasma thiobarbituric acid reactive substances (TBARs) and hydrogen peroxide production in E2 were found to be higher than those in other groups. The high activity of lactic acid dehydrogenase $(\mathrm{LDH})$ in the plasma indicated that cell membrane damage was occurred. This damage was accompanied by elevation of lipid peroxidation and in the same time by reduction of SOD and CAT activity. Supplementation of basal diet with the different concentrations of studied minerals led to improve the activity of antioxidants enzymes (SOD and CAT) and decrease in TBARs and $\mathrm{LDH}$ activity.
\end{abstract}

\section{INTRODUCTION}

Oxidative stress has been defined as a loss of balance between free-radical or reactive oxygen species (ROS) production and the antioxidant system, with negative effect on the metabolism of carbohydrate, lipids, and proteins. Oxidative stress has been linked to cardiovascular and infectious diseases, cancer, diabetes, and neurodegenerative pathologies (Kurtoglu et al 2003). A variety of different ROS are generated daily in the body, often from multiple sites. In general, the reactive oxygen species are formed with exposure to substances such as smog, ozone, chemicals, drugs, radiation, and high oxygen, among others, and during normal physiological processes (Groff and Gropper, 2000). Human defenses against ROS induced damage include the enzymes catalase and glutathione peroxidase (both of which remove $\mathrm{H}_{2} \mathrm{O}_{2}$ ), as well as superoxide dismutase (SOD), which catalyzes the dismutation of $\mathrm{O}_{2}{ }^{--}$to form $\mathrm{H}_{2} \mathrm{O}_{2}$ and $\mathrm{O}_{2}^{--}$(Erdeve et al 2004).

Superoxide dismutases [EC1.15.1.1] are metalloproteins and can be classified into three types. $\mathrm{Cu} / \mathrm{Zn}-, \mathrm{Mn}-$, and Fe-SOD, depending on the metal found in the active site. $\mathrm{Cu} / \mathrm{Zn}$ - SOD is predominantly associated with eukaryotes in the cytosolic fraction and is very sensitive to cyanide and hydrogen peroxide. Mn-SOD is associated with mitochondria and insensitive to cyanide and hydrogen peroxide. Fe-SOD is found in prokaryotes and is not sensitive to cyanide but is inhibited by hydrogen peroxide (Ken et al 2003). 
Catalase [EC 1.11.1.6] is another key enzyme involved in the removal of hydrogen peroxide (Groff and Gropper, 2000). This enzyme is heme iron-dependent and found mostly in cell peroxisomes (cytoplasmic organelles where lost of hydrogen peroxide is produced during oxidation of very long-chain fatty acids among other molecules) with small amounts of the enzyme also found in the cytosol, mitochondria, and microsomes of cells. Neutrophils and other white blood cells contain fairly high quantities of catalase to dispose of hydrogen peroxide no longer needed in the respiratory burst required for phagocytosis of foreign bacteria, viruses, and fungi.

Glutathione-S-transferase plays an important rule in the detoxification of xenobiotics, including $\mathrm{CCl}_{4}$, alcohol, and $\mathrm{H}_{2} \mathrm{O}_{2}$. GST is involved in cellular detoxification. Due to the sensitivity of these enzymes (GSH-Px, GST and GSH) to environmental pollutants and drugs, they have been used as markers of the toxic effects of ingestion or inhalation of various xenobiotics (Guven, 2005). The activity of this enzyme is impaired if selenium or iron status are poor. Because of selenium's role in glutathione peroxidase and GST the mineral is considered an antioxidant nutrient (Groff and Gropper, 2000). On the other hand, more than half of the GST activity was very resistant to hydrogen peroxide treatment (Neefjes et al 2007).

Zinc ( $\mathrm{Zn})$ is an essential component for maintenance of membrane structure, function and numerous enzyme activities. Moreover, zinc has also been considered to be a potent antioxidant defense, as it has been documented to scavenge the free radicals, which are the causative factors for lipid peroxidation (Pathak et al 2004). Therefore, dietary $\mathrm{Zn}$ deficiency leads to various pathological conditions in the epithelium of skin and intestinal mucosa; the nervous, endocrine, and immune system; and vascular endothelium in humans and experimental animals. In humans, particularly young and aged people are currently in a Zn-subdeficient state. The human body has between $1.5 \mathrm{~g}$ and $2.5 \mathrm{~g} \mathrm{Zn}$, making it nearly as abundant as iron. Zn has structural, catalytic (enzymatic), and regulatory roles. Many enzymes require $\mathrm{Zn}$ for their activities, including the RNA polymerases. Zinc supplementation has already proven beneficial in male sterility and reducing complications during pregnancy (Sun et al 2005). At present, food and tablets supplemented with $\mathrm{Zn}$ are sold for purpose of maintaining good health in Japan, the United States, and European countries (Sato et al 2003).
Copper $(\mathrm{Cu})$ is an essential trace element and is an integral component of many enzymes and proteins needed in wide range of metabolic processes. The biological functions of copper include electron-transfer catalysis by mean of its two accessible oxidation states. Excess copper; however is extremely toxic, leading to many pathological conditions that are consistent with oxidative damage to membranes and molecules. The balance between deficiency and toxicity reflects the biological role. Exposure to high levels of copper results in various changes in tissues. Copper has been shown to cause oxidative stress and lipid peroxidation (Ozcelik et al 2003).

Iron $(\mathrm{Fe})$ is capable of catalyzing the transformation of hydrogen peroxide to the highly reactive hydroxyl radical. In addition, iron can catalyze the decomposition of lipid hydro-peroxides to form alkoxyl, peroxyl and other radicals (Ibrahim et al 1997). Iron deficiency is the most common nutritional deficiency worldwide, with negative effects on work capacity and on motor and mental development of infants, children, and adolescents. Also, maternal iron-deficiency anemia (IDA) is associated with low birth weight and preterm delivery. Iron deficiency can lead not only to anemia but also to abnormal neurotransmitter function and immunologic and inflammatory defenses (Kurtoglu et al 2003). Iron is essential for maintaining proper cell function; it is normally tightly controlled by transport and storage protein. Iron overload, however, may result in deleterious reactions such degradation of protein and nuclic acids, and peroxidation of PUFA (Ibrahim et al 1997).

Generally, the antioxidant enzymes dependent on the presence of trace element as cofactors like selenium (Se), zinc $(\mathrm{Zn})$, copper $(\mathrm{Cu})$, manganese $(\mathrm{Mn})$, and iron $(\mathrm{Fe})$ without these element the enzyme activity in body is impaired, for example SOD is found in the cytoplasm, where it is dependent on the presence of two minerals, zinc and copper. In the absence of copper, SOD activity in the cytoplasm is impaired (Groff and Gropper, 2000).

In this study, we aimed to determine the improving effect of $\mathrm{Zn}, \mathrm{Cu}$, and $\mathrm{Fe}$ supplementation on SOD, CAT, and GST in rats. Also, we studied optimal concentrations of these minerals which can elevate the antioxidants enzyme activities. These enzymes can increase the protection against free radical which may cause cell damage and several diseases. 


\section{MATERIALS AND METHODS}

\section{Animal feeding experiment}

Fifty four male Sprague-Dawely strain rats, weighing from 80 to $100 \mathrm{gm}$ were obtained from Helwan Station for experimental animals, Helwan, Cairo, Egypt. The animals were housed in stainless steel cages raised in the animal house of Biochemistry Department, Faculty of Agriculture, Cairo University. The rats were kept under normal healthy laboratory conditions and temperature was adjusted at $25 \pm 2^{\circ} \mathrm{C}$ for 12 hour light dark. Animals were adapted on free access of water, and were fed for one week before the initiation of the experiment.

Composition of the basal diet $(\mathbf{g} / \mathbf{k g})$ : Casein, 217; cornstarch, 603; sucrose, 50; vegetable oil, 80 ;mineral mix ( deficient in zinc, copper and iron), 40 and vitamin mix, 10 (Sun et al 2005). The water was used and administered rats was redistilled and deionized.

\section{The experimental design}

The rats were weighed and randomly divided into 9 groups each of 6 rats was fed on the basal diet. Group 1 (E1) was fed on adequate amount of zinc as zinc oxide (ZA; $35 \mathrm{mg} \mathrm{Zn} / \mathrm{kg}$ diet), copper as copper sulfate (CA; $6.3 \mathrm{mg} \mathrm{Cu} / \mathrm{kg}$ diet) and iron as ferric citrate ( FA; $50 \mathrm{mg} \mathrm{Fe} / \mathrm{kg} \mathrm{diet}$ ). Group 2 (E2) was fed on deficient diet in Zn (ZD; $2.5 \mathrm{mg}$ $\mathrm{Zn} / \mathrm{kg}$ diet $), \mathrm{Cu}(\mathrm{CD} ; 1.2 \mathrm{mg} \mathrm{Cu} / \mathrm{kg}$ diet) and $\mathrm{Fe}$ (FD; $10 \mathrm{mg} \mathrm{Fe} / \mathrm{kg}$ diet). Group 3 (E3) was fed on diet deficient in $\mathrm{Zn}$ and containing adequate amount of $\mathrm{Cu}$ and iron. Group 4 (E4) was fed on diet deficient in $\mathrm{Cu}$ and containing adequate amount of $\mathrm{Zn}$ and Fe. Group 5 (E5) was fed on diet deficient in $\mathrm{Fe}$ and containing adequate amount of $\mathrm{Zn}$ and $\mathrm{Cu}$. Group 6 (E6) was fed on diet supplemented with high concentrations of $\mathrm{Zn}$ (ZH; $175 \mathrm{mg} \mathrm{Zn/kg} \mathrm{diet),} \mathrm{Cu}(\mathrm{CH} ; 25 \mathrm{mg} \mathrm{Cu} / \mathrm{kg}$ diet) and $\mathrm{Fe}(\mathrm{FH} ; 230 \mathrm{mg}$ Fe/kg diet).Group 7 (E7) was fed on diet supplemented with high concentration of $\mathrm{Zn}$ and containing adequate amount of $\mathrm{Cu}$ and Fe. Group 8 (E8) was fed on diet supplemented with high concentration of $\mathrm{Cu}$ and containing adequate amount of $\mathrm{Zn}$ and Fe. Group 9 (E9) was fed on diet supplemented with high concentration of $\mathrm{Fe}$ and containing adequate amount of $\mathrm{Zn}$ and $\mathrm{Cu}$.

\section{Biological parameters}

\section{Growth of rats}

The rats were weighed twice weekly; total feed intake of each rat was weighed and feed conversion efficiency, (gain of rat weigh / total feed intake, g) was calculated. At the end of the experimental period, rats were weighed and killed by diethyl ether.

\section{Blood sampling}

Blood samples were collected at the end of the experiment from the eye plexuses by a fine capillary glass tubes. Each sample was collected into both heparinized tubes to obtain the plasma and into a dry clean centrifuge glass tube without any coagulant to prepare serum. Blood was left for 15 min at room temperature, then the tubes were centrifuged for $10 \mathrm{~min}$ at $1500 \mathrm{rpm}$ and the clean supernatant serum was kept frozen at $-20^{\circ} \mathrm{C}$ untill the time of analysis to determine total-cholesterol, HDL-cholesterol, LDL-cholesterol, triglycerides, thiobarbituric acid reactive substances (TBARS), hydrogen peroxide, lactic acid dehydrogenase (LDH), superoxide dismutase (SOD) and catalase and glutathione $\mathrm{S}$ - transferase (GST) activity.

\section{Preparation of organ sample}

Liver, kidney, heart and brain were isolated and rinsed by ice cold- $\mathrm{KCl}$ solution $(0.15 \mathrm{~mol} / \mathrm{l})$ to remove erythrocytes. The solid tissues were frozen at $-20^{\circ} \mathrm{C}$ in the $\mathrm{KCl}$ solution. To assay superoxide dismutase (SOD), catalase (CAT), and glutathione-S-transferase (GST) activity in the studied organs, sample homogenate $(25 \% \mathrm{~W} / \mathrm{V})$ was prepared in deionized water and centrifuged at $13.000 \mathrm{~g}$ for $20 \mathrm{~min}$. The supernatant was collected and used for further determination (Waschuleulewski and Sunde, 1988).

\section{Biochemical assay}

The activity of superoxide dismutase (SOD), catalase (CAT), and glutathione $\mathrm{S}$ - transferase (GST), of rats plasma and organs samples were estimated according to [Nishikimi et al (1972), Aebi (1984), and Habig \& Pabst, (1974)] respectively, using kits obtained from Biodiagnostic. Lipid peroxidation level (Malondialdehyde, MDA), and hydrogen peroxide of rats blood serum were estimated according to Metlzer et al (1997), 
and (Lacy et al 1998), respectively; using kits obtained from Biodiagnostic. Also, Lactate dehydrogenase $(\mathrm{LDH})$ of rats blood serum was determined by enzymatic colorimetric method according to Rec (1972). Plasma total cholesterol, HDLcholesterol and LDL-cholesterol, triglycerides, were determined by using the methods described by Roeschlau et al (1974), Assmann (1979), Wieland \& Seidel (1983), and Trinder (1969), respectively; using kits obtained from Randox Laboratories Ltd., Diamond Road, Crumlin, Co. Antrim, United Kigdom, BT 29 Qy.

\section{Statistical analysis}

The obtained data of biological examination were statistically analyzed by the least significant differences (L.S.D) at the 5\% level of probability procedure according to Snedecor and Cochran (1980).

\section{RESULTS AND DISCUSSION}

\section{Growth and feed conversion efficiency}

Data in Table (1) show changes in the weight and the feed conversion efficiency (FCE) of the tested rat groups. Significant differences between groups in total weight change were noticed. The highest accumulated weight gain was recorded by group E1, E7 and E9, which were fed on basal diet, high level of zinc $(\mathrm{ZH})$ and high level of iron (FH), respectively. However, the lowest accumulated gain was observed when rats were fed on diet deficient in $\mathrm{Zn}$ (E3) and diet deficient in $\mathrm{Zn}, \mathrm{Cu}$ and $\mathrm{Fe}(\mathrm{E} 2)$. In the same time, fed conversion efficiency (FCE) was also decreased by zinc and / or iron deficiency as illustrated in Table (1) by group E2, E3 and E5. The loss in rat weight may be due to anorexia or poor food efficiency that caused by zinc or iron deficiency. Also iron deficiency reduced blood hemoglobin and hematocrit. This explanation is illustrated by Sun et al (2005).

\section{Superoxide dismutase (SOD) activity}

The effect of $\mathrm{Zn}, \mathrm{Cu}$, and Fe levels on the SOD activity in plasma, erythrocytes, liver, kidney, brain and heart of rats are presented in Table (2). The highest SOD activity in plasma was observed by rats fed on the diet supplemented with high concentration of $\mathrm{Zn}, \mathrm{Cu}$ and $\mathrm{Fe}$ (group E6). Moreover, supplementation with high concentration of Zn (group E7) lead to obtained high SOD activity in plasma compared with other studied treatments. On the other hand, SOD activity in erythrocytes, liver, brain and heart was relay improved when rats fed on diet supplemented with copper.

Feeding rats on diet deficient in one or in all studied elements led to dramatically decrease in SOD activity (Table 2).

The lowest values of SOD activity in plasma and erythrocytes were recorded by rats in group $\mathrm{E} 2$ (deficient in $\mathrm{Zn}, \mathrm{Cu}$, and $\mathrm{Fe}$ ). In liver and brain, no significant difference was recorded between SOD activity in group E2, E3 and E5. In kidney the highest SOD activity was observed when rats were fed on basal diet (E1), or on the diet supplemented with high concentration of $\mathrm{Zn}$ (E7). The results obtained in the present study demonstrated that $\mathrm{Zn}$ were required for the activity of SOD in plasma, erythrocytes, liver, kidney and brain. This could be explained by those stated by Sun et al (2005). They mentioned that $\mathrm{Zn}$ had ability to suppress free-radical production and to control the lipid peroxidation. Moreover, Asagba et al 2004 mentioned that SOD is a metaloenzyme requiring zinc for structural stability and copper for enzymatic activity. Copper also played an important role in increasing SOD activity.They added that the increase in free radical generation can be occurred under conditions of stress such as malnutrition. Therefore, it follows that the observed decrease in SOD activity would diminish the ability of the tissues to scavenge free radicals, this could be explain the lowest SOD activity observed by rats fed on $\mathrm{Zn}, \mathrm{Cu}$ and $\mathrm{Fe}$ deficient diet. Reimers et al (2003) mentioned that several factors may contribute to lipid peroxidation in cirrhotic liver, as increased iron and copper content, excessive free radical production, decreased availability of antioxidant as enzyme (SOD, CAT, and glutathione peroxidase), vitamins (vitamin E), or (Se, $\mathrm{Zn}$ ). However, they indicated that adequate to moderate intake of $\mathrm{Cu}$ are beneficial both in preventing iron overload and optimizing the antioxidant defense (Roughead et al 1999). There was correlation between the increase in zinc concentration and decrease copper concentration (Kocaturk et al 2004) as previously mentioned. Also, our results were in agreement with Prohaska and Gybina (2004) who found that in some tissue such as liver and brain SOD levels are markedly lower following copper deficiency. There were significant positive correlations between erythrocyte SOD activity and erythrocyte $\mathrm{Cu}$ concentration (Guo et al 2004). 
Table 1.Growth of rats fed on different concentrations of mineral (zinc, copper and iron) for 6 weeks

\begin{tabular}{|lccccc|}
\hline \multicolumn{1}{|c}{ Treatments* } & $\begin{array}{c}\text { Initial weight } \\
(\mathrm{g})\end{array}$ & $\begin{array}{c}\text { Final weight } \\
(\mathrm{g})\end{array}$ & $\begin{array}{c}\text { Total weight } \\
\text { change }(\mathrm{g})\end{array}$ & $\begin{array}{c}\text { Feed } \\
\text { intake }(\mathrm{g})\end{array}$ & $\begin{array}{c}\text { Feed conversion } \\
\text { efficiency, (F.C.E) } \\
(\mathrm{g} \text { gain/g feed) }\end{array}$ \\
\hline E1 (ZA, CA,FA) & $90.83 \pm 4.82^{\mathrm{a}}$ & $228.25 \pm 3.60^{\mathrm{ab}}$ & $137.42 \pm 3.81^{\mathrm{ab}}$ & $473.86 \pm 23.45^{\mathrm{b}}$ & $0.29 \pm 0.01^{\mathrm{ab}}$ \\
E2 (ZD, CD,FD) & $91.02 \pm 5.79^{\mathrm{a}}$ & $161.70 \pm 2.73^{\mathrm{e}}$ & $70.68 \pm 5.19^{\mathrm{e}}$ & $336.57 \pm 20.48^{\mathrm{d}}$ & $0.21 \pm 0.04^{\mathrm{c}}$ \\
E3 (ZD) & $90.04 \pm 3.88^{\mathrm{a}}$ & $157.03 \pm 6.89^{\mathrm{e}}$ & $66.90 \pm 2.98^{\mathrm{e}}$ & $290.87 \pm 11.21^{\mathrm{e}}$ & $0.23 \pm 0.01^{\mathrm{bc}}$ \\
E4 (CD) & $90.38 \pm 5.02^{\mathrm{a}}$ & $219.31 \pm 4.89^{\mathrm{c}}$ & $128.93 \pm 4.82^{\mathrm{c}}$ & $430.50 \pm 18.48^{\mathrm{c}}$ & $0.30 \pm 0.02^{\mathrm{a}}$ \\
E5 (FD) & $90.52 \pm 3.52^{\mathrm{a}}$ & $183.55 \pm 8.12^{\mathrm{d}}$ & $93.03 \pm 6.19^{\mathrm{d}}$ & $422.86 \pm 21.56^{\mathrm{b}}$ & $0.22 \pm 0.03^{\mathrm{c}}$ \\
E6 (ZH, CH, FH) & $89.71 \pm 4.40^{\mathrm{a}}$ & $224.09 \pm 3.52^{\mathrm{abc}}$ & $134.38 \pm 4.52^{\mathrm{abc}}$ & $479.93 \pm 9.48^{\mathrm{ab}}$ & $0.28 \pm 0.05^{\mathrm{ab}}$ \\
E7 (ZH) & $90.83 \pm 5.82^{\mathrm{a}}$ & $231.80 \pm 2.48^{\mathrm{a}}$ & $140.97 \pm 5.21^{\mathrm{a}}$ & $503.46 \pm 14.82^{\mathrm{c}}$ & $0.28 \pm 0.02^{\mathrm{ab}}$ \\
E8 (CH) & $90.48 \pm 2.91^{\mathrm{a}}$ & $221.95 \pm 6.61^{\mathrm{bc}}$ & $131.47 \pm 6.21^{\mathrm{bc}}$ & $424.10 \pm 18.42^{\mathrm{a}}$ & $0.31 \pm 0.03^{\mathrm{a}}$ \\
E9 (FH) & $90.21 \pm 5.01^{\mathrm{a}}$ & $229.04 \pm 3.82^{\mathrm{ab}}$ & $138.83 \pm 4.21^{\mathrm{ab}}$ & $514.19 \pm 15.61^{\mathrm{a}}$ & $0.27 \pm 0.01^{\mathrm{ab}}$ \\
\hline L.S.D (P<0.05) & 7.20 & 7.36 & 8.05 & 29.76 & 0.04 \\
\hline
\end{tabular}

Each value represents the mean \pm SE.

The mean values with different superscript alphabets indicate significant differences $(\mathrm{P} \leq 0.05)$ using LSD test

* ZD: zinc deficient; ZA: zinc adequate; ZH: zinc high; CD: copper deficient; CA: copper adequate;

$\mathrm{CH}$ : copper high; FD: iron deficient; FA: iron adequate; FH: iron high.

Table 2. Superoxide dismutase activity in the plasma, erythrocytes, liver, kidney, brain and heart of rats fed on different concentrations of mineral (zinc, copper and iron) for 6 weeks.

\begin{tabular}{|lcccccc|}
\hline & \multicolumn{7}{c}{ Superoxide dismutase activity } \\
\cline { 2 - 7 } \multicolumn{1}{c}{ Treatments* } & $\begin{array}{c}\text { Plasma } \\
\text { U/ml }\end{array}$ & $\begin{array}{c}\text { Erythrocytes } \\
\text { U/g Hb }\end{array}$ & $\begin{array}{c}\text { Liver } \\
\text { U/mg } \\
\text { protein }\end{array}$ & $\begin{array}{c}\text { Kidney } \\
\text { U/mg } \\
\text { protein }\end{array}$ & $\begin{array}{c}\text { Brain } \\
\text { U/mg } \\
\text { protein }\end{array}$ & $\begin{array}{c}\text { Heart } \\
\text { U/mg } \\
\text { protein }\end{array}$ \\
\hline E1 (ZA, CA, FA) & $254.19 \pm 17.76^{\mathrm{d}}$ & $315.85 \pm 5.16^{\mathrm{bc}}$ & $1.88 \pm 0.11^{\mathrm{e}}$ & $5.38 \pm 0.44^{\mathrm{a}}$ & $2.56 \pm 0.54^{\mathrm{d}}$ & $1.19 \pm 0.03^{\mathrm{e}}$ \\
E2 (ZD, CD, FD) & $15.24 \pm 2.72^{\mathrm{f}}$ & $75.94 \pm 6.15^{\mathrm{e}}$ & $0.47 \pm 0.06^{\mathrm{f}}$ & $2.64 \pm 0.29^{\mathrm{b}}$ & $0.86 \pm 0.06^{\mathrm{e}}$ & $0.72 \pm 0.06^{\mathrm{f}}$ \\
E3 (ZD) & $158.40 \pm 15.26^{\mathrm{e}}$ & $283.02 \pm 3.68^{\mathrm{c}}$ & $0.35 \pm 0.03^{\mathrm{f}}$ & $2.27 \pm 0.09^{\mathrm{b}}$ & $0.71 \pm 0.01^{\mathrm{e}}$ & $3.12 \pm 0.09^{\mathrm{b}}$ \\
E4 (CD) & $222.88 \pm 3.22^{\mathrm{d}}$ & $182.86 \pm 2.85^{\mathrm{d}}$ & $0.401 \pm 0.03^{\mathrm{f}}$ & $2.26 \pm 0.73^{\mathrm{b}}$ & $0.52 \pm 0.00^{\mathrm{e}}$ & $1.94 \pm 0.07^{\mathrm{c}}$ \\
E5 (FD) & $217.03 \pm 9.13^{\mathrm{d}}$ & $280.90 \pm 0.77^{\mathrm{c}}$ & $0.469 \pm 0.03^{\mathrm{f}}$ & $0.52 \pm 0.16^{\mathrm{c}}$ & $0.72 \pm 0.04^{\mathrm{e}}$ & $1.65 \pm 0.07^{\mathrm{cd}}$ \\
E6 (ZH, CH, FH) & $605.52 \pm 3.78^{\mathrm{a}}$ & $325.2 \pm 8.58^{\mathrm{bc}}$ & $3.61 \pm 0.18^{\mathrm{d}}$ & $3.05 \pm 0.36^{\mathrm{b}}$ & $4.34 \pm 0.41^{\mathrm{c}}$ & $1.31 \pm .19^{\mathrm{de}}$ \\
E7 (ZH) & $432.93 \pm 12.99^{\mathrm{b}}$ & $368.76 \pm 20.15^{\mathrm{b}}$ & $6.30 \pm 0.51^{\mathrm{b}}$ & $4.65 \pm 0.14^{\mathrm{a}}$ & $13.24 \pm 0.23^{\mathrm{b}}$ & $0.29 \pm 0.07^{\mathrm{g}}$ \\
E8 (CH) & $220.53 \pm 13.61^{\mathrm{d}}$ & $499.38 \pm 49.72^{\mathrm{a}}$ & $13.87 \pm 0.72^{\mathrm{a}}$ & $2.44 \pm 0.24^{\mathrm{b}}$ & $22.93 \pm 0.84^{\mathrm{a}}$ & $4.80 \pm 0.17^{\mathrm{a}}$ \\
E9 (FH) & $299.97 \pm 18.38^{\mathrm{c}}$ & $364.61 \pm 8.12^{\mathrm{b}}$ & $4.65 \pm 0.35^{\mathrm{c}}$ & $2.05 \pm 0.17^{\mathrm{b}}$ & $4.73 \pm 0.52^{\mathrm{c}}$ & $1.67 \pm 0.26^{\mathrm{cd}}$ \\
\hline L.S.D (P<0.05) & 36.46 & 59.41 & 0.97 & 1.02 & 1.21 & 0.40 \\
\hline
\end{tabular}

Each value represents the mean $\pm \mathrm{SE}$.

The mean values in the same column with different superscript alphabets indicate significant differences $(\mathrm{P}<0.05)$ using LSD test. * See Table (1). 
Kurtoglu et al (2003) measured the oxidant and antioxidant status in IDA patients and found that the antioxidant enzyme such as SOD and CAT were significantly lower in IDA patient compared to normal human, decreased SOD and CAT, and these finding were in agreement with our results.

\section{Catalase(CAT) activity}

Catalase is another key factor involved in the removal of hydrogen peroxide. This enzyme is heme iron-dependent (Groff and Gropper, 2000). Catalase activity (CAT) in plasma, erythrocyte, liver, kidney, brain, and heart are summarized in Table (3). In the rats fed on diet with high level in $\mathrm{Zn}, \mathrm{Cu}$, and $\mathrm{Fe}$ (group E6) or high level of $\mathrm{Zn}$ (ZH; group E7), showed significant increase in CAT activity in plasma compared with rats in group E1. The highest CAT activity in plasma can be interpreted by those reported by Akcil et al (2004). They mentioned that a positive correlation was found between CAT activity and plasma zinc concentrations. Also, they found that at starvation level of zinc, SOD and CAT activities were significantly reduced resulted in malignant tumor group.

Increasing of iron level in the diet (E9) led to no significant improvement in CAT activity in plasma compared with E1. Also, there is no effect of $\mathrm{Cu}$ on CAT activity in plasma as illustrated in group E8 and group E4 in plasma. However, supplementation of diet with high level of copper (E8) led to obtain the highest CAT activity value in erythrocytes.

Fortification of diet with high levels of $\mathrm{Zn}, \mathrm{Cu}$ and Fe (E6) led to significant improvement of the values of CAT activity in all studied organs. Moreover, at high level of zinc, rats in group E7 observed high value of CAT activity in both liver and brain (Table 3).

Our results demonstrated that, the determined activity was remarkably reduced by feeding on diet deficient in iron (E5) or in all studied elements (E2). This finding was agreement with Kurtoglu et al (2003) who found that in state of iron deficiency CAT activity was decreased whereas, oxidative stress was decreased when diet was supplemented with Fe after 6 wk. This condition remains without significant changes until the end of their study, suggesting that the oxidant-antioxidant status is regulated at the same time as the normalization of hemoglobin. They confirmed that oral iron supplementation is recommended for the recovery of the impaired antioxidant defense system in iron deficiency anemia. In previous study, Miret et al (2003) showed that rats fed on fish oil (FO) had an increase in iron absorption compared with rats fed basal diet.

\section{Glutathione-S- transferase (GST) activity}

Glutathione-S- transferase activity in plasma, erythrocytes, liver, kidney, brain and heart of rats fed on different concentrations of zinc, copper and iron are shown in Table (4). These data indicated significant increase in GST activity in rats due to feeding on diet deficient in $\mathrm{Zn}, \mathrm{Cu}$ and iron (group E 2). In contrary to SOD and CAT activities, group E2 showed highest GST activity where the diet is deficient in all studied elements $(\mathrm{Zn}, \mathrm{Cu}$ and $\mathrm{Fe}$ ). Present results are in agreement with those obtained by Kraus et al (1997) who found that, dietary zinc-deficient rats indicate an increase in oxidative processes, reduction of glutathione concentration and glutathione peroxidase activity resulted increasing of GST activity in rats, mice and humans. In a recent study, zinc, copper and iron supplementation was used to recover the antioxidant defense system (Kurtoglu et al 2003).

On the other hand, excessive free-radical production, decreased availability of antioxidants as enzymes (SOD, catalase and glutathione peroxidase), vitamins (vitamin E) or trace elements (selenium and zinc) Guo et al (2004) and Cellular glutathione and related enzymes such as glutathione-S-tranferase, glutathione reductase and glutathione peroxidase are among the principal protective mechanism against endogenous and exogenous toxic substances and free radicals-mediated damage in liver tissues as well as in other tissues (Czeczot et al 2006).

\section{Malondialdehyde, hydrogen peroxide and lactic acid dehydrogenase}

Malondialdehyde concentration, hydrogen peroxide production and lactic acid dehydrogenase activity in serum were measured in Table (5). Data indicate that, in rats fed on diet deficient in zinc, copper and iron (E2), the concentration of malondialdehyde, hydrogen peroxide production and lactic acid dehydrogenase (LDH) activity were $3.50 \mathrm{nmol} / \mathrm{L}, 13.5 \mu \mathrm{mol} / \mathrm{L}$ and $154.39 \mathrm{U} / \mathrm{L}$ respectively. These values were significantly higher than those of other studied groups, which 
Table 3. Catalase activity in the plasma, erythrocytes, liver, kidney, brain and heart of rats fed on different concentrations of mineral (zinc, copper and iron) for 6 weeks

\begin{tabular}{|lcccccc|}
\hline & \multicolumn{5}{c|}{ Catalase activity } \\
\cline { 2 - 7 } Treatments* & $\begin{array}{c}\text { Plasma } \\
\text { U/ml }\end{array}$ & $\begin{array}{c}\text { Erythrocytes } \\
\text { U/g Hb }\end{array}$ & $\begin{array}{c}\text { Liver } \\
\text { U/g protein }\end{array}$ & $\begin{array}{c}\text { Kidney } \\
\text { U/g protein }\end{array}$ & $\begin{array}{c}\text { Brain } \\
\text { U/g protein }\end{array}$ & $\begin{array}{c}\text { Heart } \\
\text { U/g protein }\end{array}$ \\
\hline E1 (ZA, CA, FA) & $0.063 \pm 0.001^{\mathrm{b}}$ & $0.73 \pm 0.03^{\mathrm{d}}$ & $1.23 \pm 0.07^{\mathrm{b}}$ & $2.59 \pm 0.10^{\mathrm{bc}}$ & $1.35 \pm 0.25^{\mathrm{b}}$ & $1.36 \pm 0.19^{\mathrm{c}}$ \\
E2 (ZD, CD, FD) & $0.034 \pm 0.002^{\mathrm{e}}$ & $0.36 \pm 0.03^{\mathrm{f}}$ & $0.75 \pm 0.07^{\mathrm{de}}$ & $1.73 \pm 0.16^{\mathrm{de}}$ & $0.34 \pm 0.02^{\mathrm{c}}$ & $0.43 \pm 0.05^{\mathrm{d}}$ \\
E3 (ZD) & $0.051 \pm 0.003^{\mathrm{c}}$ & $0.50 \pm 0.02^{\mathrm{ef}}$ & $0.55 \pm 0.05^{\mathrm{e}}$ & $2.27 \pm 0.15^{\mathrm{cd}}$ & $0.33 \pm 0.02^{\mathrm{c}}$ & $0.71 \pm 0.02^{\mathrm{d}}$ \\
E4 (CD) & $0.063 \pm 0.001^{\mathrm{b}}$ & $0.59 \pm 0.06^{\mathrm{e}}$ & $0.29 \pm 0.03^{\mathrm{f}}$ & $1.39 \pm 0.08^{\mathrm{e}}$ & $0.42 \pm 0.09^{\mathrm{c}}$ & $0.70 \pm 0.02^{\mathrm{d}}$ \\
E5 (FD) & $0.042 \pm 0.004^{\mathrm{d}}$ & $0.42 \pm 0.04^{\mathrm{f}}$ & $0.93 \pm 0.08^{\mathrm{cd}}$ & $1.45 \pm 0.08^{\mathrm{e}}$ & $0.27 \pm 0.0^{\mathrm{c}}$ & $0.78 \pm 0.04^{\mathrm{d}}$ \\
E6 (ZH, CH, FH) & $0.088 \pm 0.002^{\mathrm{a}}$ & $0.99 \pm 0.04^{\mathrm{c}}$ & $1.77 \pm 0.16^{\mathrm{a}}$ & $4.04 \pm 0.40^{\mathrm{a}}$ & $1.24 \pm 0.09^{\mathrm{b}}$ & $2.50 \pm 0.09^{\mathrm{a}}$ \\
E7 (ZH) & $0.084 \pm 0.004^{\mathrm{a}}$ & $1.18 \pm 0.06^{\mathrm{b}}$ & $1.82 \pm 0.12^{\mathrm{a}}$ & $3.07 \pm 0.35^{\mathrm{b}}$ & $1.94 \pm 0.21^{\mathrm{a}}$ & $1.77 \pm 0.27^{\mathrm{bc}}$ \\
E8 (CH) & $0.049 \pm 0.001^{\mathrm{cd}}$ & $1.37 \pm 0.07^{\mathrm{a}}$ & $1.13 \pm 0.02^{\mathrm{bc}}$ & $2.55 \pm 0.12^{\mathrm{bc}}$ & $0.29 \pm 0.02^{\mathrm{c}}$ & $2.31 \pm 0.24^{\mathrm{ab}}$ \\
E9 (FH) & $0.065 \pm 0.003^{\mathrm{b}}$ & $1.39 \pm 0.04^{\mathrm{a}}$ & $1.08 \pm 0.09^{\mathrm{bc}}$ & $2.12 \pm 0.01^{\mathrm{cd}}$ & $0.63 \pm 0.08^{\mathrm{c}}$ & $2.20 \pm 0.19^{\mathrm{ab}}$ \\
\hline L.S.D (P<0.05) & 0.008 & 0.14 & 0.26 & 0.59 & 0.35 & 0.61 \\
\hline
\end{tabular}

Each value represents the mean \pm SE.

The mean values in the same column with different superscript alphabets indicate significant differences $(\mathrm{P}<0.05)$ using LSD test.

* See Table (1).

Table 4. Glutathione S- transferase activity in the plasma, erythrocytes, liver, kidney, brain and heart of rats fed on different concentrations of mineral (zinc, copper and iron) for 6 weeks

\begin{tabular}{|lcccccc|}
\hline & \multicolumn{5}{c|}{ Glutathione S-transferase activity } \\
\cline { 2 - 7 } Treatments* & $\begin{array}{c}\text { Plasma } \\
\text { U/L }\end{array}$ & $\begin{array}{c}\text { Erythrocytes } \\
\text { U/g Hb }\end{array}$ & $\begin{array}{c}\text { Liver } \\
\text { U/g protein }\end{array}$ & $\begin{array}{c}\text { Kidney } \\
\text { U/g protein }\end{array}$ & $\begin{array}{c}\text { brain } \\
\text { U/g protein }\end{array}$ & $\begin{array}{c}\text { heart } \\
\text { Ug protein }\end{array}$ \\
\hline E1 (ZA, CA, FA) & $1199.04 \pm 6.37^{\mathrm{e}}$ & $2.57 \pm 0.37^{\mathrm{e}}$ & $361.15 \pm 16.35^{\mathrm{d}}$ & $74.85 \pm 11.75^{\mathrm{d}}$ & $85 \pm 2.8^{\mathrm{cd}}$ & $85 \pm 2.8^{\mathrm{cd}}$ \\
E2 (ZD, CD, FD) & $2711.51 \pm 64.61^{\mathrm{a}}$ & $18 \pm 0.97^{\mathrm{a}}$ & $1063.93 \pm 27.88^{\mathrm{a}}$ & $263.6 \pm 5.7^{\mathrm{a}}$ & $159.25 \pm 7.45^{\mathrm{a}}$ & $159.25 \pm 7.45^{\mathrm{a}}$ \\
E3 (ZD) & $2137.95 \pm 13.92^{\mathrm{c}}$ & $14.59 \pm 2.37^{\mathrm{b}}$ & $800.92 \pm 30.48^{\mathrm{b}}$ & $209.25 \pm 10.25^{\mathrm{b}}$ & $100.25 \pm 4.25^{\mathrm{bc}}$ & $100.25 \pm 4.25^{\mathrm{bc}}$ \\
E4 (CD) & $1686.95 \pm 45.25^{\mathrm{d}}$ & $6.02 \pm 0.24^{\mathrm{d}}$ & $560.9 \pm 83.1^{\mathrm{c}}$ & $86.75 \pm 15.15^{\mathrm{d}}$ & $87.9 \pm 2.6^{\mathrm{cd}}$ & $87.9 \pm 2.6^{\mathrm{cd}}$ \\
E5 (FD) & $1697.63 \pm 34.58^{\mathrm{d}}$ & $8.45 \pm 1.10^{\mathrm{cd}}$ & $443.95 \pm 15.65^{\mathrm{cd}}$ & $60.3 \pm 17.47^{\mathrm{d}}$ & $76.4 \pm 10^{\mathrm{d}}$ & $76.4 \pm 10^{\mathrm{d}}$ \\
E6 (ZH, CH, FH) & $2458.69 \pm 67.66^{\mathrm{b}}$ & $11.60 \pm 1.07^{\mathrm{bc}}$ & $826.5 \pm 4.9^{\mathrm{b}}$ & $145.85 \pm 1.85^{\mathrm{c}}$ & $111.85 \pm 7.35^{\mathrm{b}}$ & $111.85 \pm 7.35^{\mathrm{b}}$ \\
E7 (ZH) & $1364.24 \pm 98.84^{\mathrm{e}}$ & $7.35 \pm 0.35^{\mathrm{d}}$ & $502.65 \pm 74.35^{\mathrm{cd}}$ & $79.2 \pm 2.4^{\mathrm{d}}$ & $72.4 \pm 6^{\mathrm{d}}$ & $72.4 \pm 6^{\mathrm{d}}$ \\
E8 (CH) & $1659.25 \pm 47.89^{\mathrm{d}}$ & $9.17 \pm 0.24^{\mathrm{cd}}$ & $464.65 \pm 36.35^{\mathrm{cd}}$ & $92.2 \pm 3.5^{\mathrm{d}}$ & $72.7 \pm 2.5^{\mathrm{d}}$ & $78.3 \pm 6^{\mathrm{d}}$ \\
E9 (FH) & $1678.49 \pm 17.66^{\mathrm{d}}$ & $6.30 \pm 0.1^{\mathrm{d}}$ & $437 \pm 49^{\mathrm{cd}}$ & $80.34 \pm 3.62^{\mathrm{d}}$ & $78.3 \pm 6^{\mathrm{d}}$ & $80.34 \pm 3.62^{\mathrm{d}}$ \\
\hline L.S.D (P<0.05) & 181.47 & 3.24 & 144.64 & 30.97 & 19.09 & 19.09 \\
\hline
\end{tabular}

Each value represents the mean \pm SE.

The mean values in the same column with different superscript alphabets indicate significant differences $(\mathrm{P}<0.05)$ using LSD test.

* See Table (1). 
Table 5. Malondialdehyde, hydrogen peroxides $\left(\mathrm{H}_{2} \mathrm{O}_{2}\right)$ and lactic acid dehydrogenase activity in serum of rats fed on different concentrations of mineral ( zinc, copper and iron) for 6 weeks

\begin{tabular}{|lccc|}
\hline Treatments* & $\begin{array}{c}\text { Malondialdehyde } \\
(\mathrm{nmol} / \mathrm{L})\end{array}$ & $\begin{array}{c}\mathrm{H}_{2} \mathrm{O}_{2} \\
(\mu \mathrm{mol} / \mathrm{L})\end{array}$ & $\begin{array}{c}\mathrm{LDH} \\
(\mathrm{U} / \mathrm{L})\end{array}$ \\
\hline E 1 (ZA, CA,FA) & $0.53 \pm 0.05^{\mathrm{e}}$ & $7 \pm 1^{\mathrm{bc}}$ & $85.67 \pm 4.77^{\mathrm{c}}$ \\
E2 (ZD, CD,FD) & $3.50 \pm 0.10^{\mathrm{a}}$ & $13.5 \pm 0.5^{\mathrm{a}}$ & $154.39 \pm 5.61^{\mathrm{a}}$ \\
E3 (ZD) & $0.88 \pm 0.02^{\mathrm{de}}$ & $7.5 \pm 0.5^{\mathrm{bc}}$ & $81.63 \pm 2.54^{\mathrm{c}}$ \\
E4 $(\mathrm{CD})$ & $1.01 \pm 0.41^{\mathrm{cde}}$ & $5.5 \pm 0.5^{\mathrm{c}}$ & $89.57 \pm 9.34^{\mathrm{c}}$ \\
E5 (FD) & $1.43 \pm 0.20^{\mathrm{bcd}}$ & $7 \pm 2^{\mathrm{bc}}$ & $79.60 \pm 0.5^{\mathrm{c}}$ \\
E6 $(\mathrm{ZH}, \mathrm{CH}, \mathrm{FH})$ & $1.48 \pm 0.37^{\mathrm{cd}}$ & $7 \pm 1^{\mathrm{bc}}$ & $105.1 \pm 5.07^{\mathrm{b}}$ \\
E7 $(\mathrm{ZH})$ & $1.50 \pm 0.05^{\mathrm{bc}}$ & $5 \pm 2^{\mathrm{c}}$ & $83.19 \pm 2.64^{\mathrm{c}}$ \\
E8 $(\mathrm{CH})$ & $1.67 \pm 0.19^{\mathrm{b}}$ & $4.5 \pm 0.50^{\mathrm{c}}$ & $84.85 \pm 0.47^{\mathrm{c}}$ \\
E9 $(\mathrm{FH})$ & $0.88 \pm 0.02^{\mathrm{de}}$ & $4.5 \pm 0.5^{\mathrm{c}}$ & $79.94 \pm 4^{\mathrm{c}}$ \\
\hline L.S.D $(\mathrm{P}<0.05)$ & 0.56 & 3.46 & 14.96 \\
\hline
\end{tabular}

Each value represents the mean \pm SE.

The mean values in the same column with different superscript alphabets indicate significant differences $(\mathrm{P}<0.05)$ using LSD test

* See Table (1).

fed on diets supplemented with different concentration of minerals ( $\mathrm{Zn}, \mathrm{Cu}$ and iron). The increasing of hydrogen peroxide in plasma can be explained by the findings of Lacy et al (2000). They who found that hydrogen peroxide can be produced by of dismutation of superoxide radicals through the activity of superoxide dismutase. Also, hydrogen peroxide levels may be influenced and regulated by action of antioxidants including the enzymes CAT, GST and glutathione peroxidase (GSH-Px) activity. When $\mathrm{H}_{2} \mathrm{O}_{2}$ was produced in excess amount, reactive oxygen species (ROS) can seriously alter the structure of biomolecules, such as proteins, lipids, lipoproteins and DNA. Oxidative DNA damage may participate in ROSinduced carcinogenesis and mutations. Cellular fatty acids are readily oxidized by ROS to produce lipid peroxyl radicals and lipid hydroperoxides. Lipid peroxyl radicals can subsequently propagate into malondialdehyde (Snezana et al 2006). Malondialdehyde itself owing to its high cytotoxicity and inhibitory action on protective enzymes (Czeczot $\boldsymbol{e t}$ al 2006). Proteins are also easily attacked by ROS and this can results in modifications in the structure, enzyme activity and signaling pathways. Zinc, Copper and iron act as cofactors antioxidant enzyme (Superoxid dismutase, cytochrom-c oxidase and catalase) defense system (Akcil et al 2004 and Kocaturk et al 2004).
The LDH activity assay is sensitive as an indicator of membrane damage. The increase in the serum activity of this enzyme was directly proportional to the degree of cellular damage and is an indicator of liver destruction Wu et al (2004). Zinc and $\mathrm{Cu}$ have been found to be associated with metal binding proteins (metallothionine and ceruloplasmine), that are known to regulate the functions of zinc and copper, scavenger of free radicals and superoxide ion and have antioxidant effects under a variety of conditions including radiations exposure toxicity, from anticancer drugs, ethanol toxicity and oxidatively mutagensis ( Powell, 2000).

\section{Lipid profile}

Data in Table (6) show the effect of dietary minerals (zinc, copper and iron) on the serum level of total cholesterol, triglycerides and concentrations of cholesterol in the major serum lipoprotein fraction (HDL and LDL). Significant increase in serum total-cholesterol $(164.67 \mathrm{mg} / \mathrm{dl}), \mathrm{TG}(167.07$ $\mathrm{mg} / \mathrm{dl})$ and LDL-c $(90.97 \mathrm{mg} / \mathrm{dl})$ were observed by rats fed on diet deficient in zinc, copper and iron (group E2) compared to rats fed diet supplemented with high concentration $\mathrm{Zn}, \mathrm{Cu}$ and Fe (E6). The present data are in agreement with the previous observations and from various experimental models, which have showed that 
Table 6. Serum total cholesterol, HDL-cholesterol, LDL-cholesterol, and triglycerides of rats fed on different concentrations of mineral ( zinc, copper and iron) for 6 weeks

\begin{tabular}{|lcccc|}
\hline \multicolumn{1}{|c}{ Treatments* } & $\begin{array}{c}\text { T.cholesterol } \\
(\mathrm{mg} / \mathrm{dl})\end{array}$ & $\begin{array}{c}\text { HDL } \\
(\mathrm{mg} / \mathrm{dl})\end{array}$ & $\begin{array}{c}\text { LDL } \\
(\mathrm{mg} / \mathrm{dl})\end{array}$ & $\begin{array}{c}\text { Triglycerides } \\
(\mathrm{mg} / \mathrm{dl})\end{array}$ \\
\hline E 1 (ZA, CA,FA) & $104.01 \pm 2.27^{\mathrm{d}}$ & $33 \pm 1.34^{\mathrm{a}}$ & $52.76 \pm 0.61^{\mathrm{d}}$ & $132.22 \pm 4.78^{\mathrm{c}}$ \\
E2 (ZD, CD,FD) & $164.67 \pm 3.62^{\mathrm{a}}$ & $26.30 \pm 1.68^{\mathrm{b}}$ & $90.97 \pm 0.11^{\mathrm{a}}$ & $167.07 \pm 0.07^{\mathrm{a}}$ \\
E3 (ZD) & $100.36 \pm 4.77^{\mathrm{d}}$ & $31.41 \pm 1.72^{\mathrm{ab}}$ & $55.4 \pm 1.15^{\mathrm{d}}$ & $152.18 \pm 1.62^{\mathrm{b}}$ \\
E4 (CD) & $102.6 \pm 6.04^{\mathrm{d}}$ & $30.6 \pm 0.44^{\mathrm{ab}}$ & $60.9 \pm 2.81^{\mathrm{cd}}$ & $149.46 \pm 4.93^{\mathrm{b}}$ \\
E5 (FD) & $142.76 \pm 0.15^{\mathrm{b}}$ & $32.55 \pm 1.96^{\mathrm{a}}$ & $67.06 \pm 1.11^{\mathrm{bc}}$ & $151.99 \pm 0.68^{\mathrm{b}}$ \\
E6 $(\mathrm{ZH}, \mathrm{CH}, \mathrm{FH})$ & $119.30 \pm 3.81^{\mathrm{c}}$ & $30.63 \pm 1.29^{\mathrm{ab}}$ & $73.76 \pm 2.50^{\mathrm{b}}$ & $137.71 \pm 9.87^{\mathrm{bc}}$ \\
E7 $(\mathrm{ZH})$ & $113.70 \pm 6.98^{\mathrm{cd}}$ & $30.31 \pm 1.59^{\mathrm{ab}}$ & $57.31 \pm 6.36^{\mathrm{d}}$ & $147.09 \pm 3.56^{\mathrm{bc}}$ \\
E8 $(\mathrm{CH})$ & $138.04 \pm 0.36^{\mathrm{b}}$ & $30.79 \pm 2.76^{\mathrm{ab}}$ & $58.69 \pm 1.78^{\mathrm{d}}$ & $143.37 \pm 1.41^{\mathrm{bc}}$ \\
E9 $(\mathrm{FH})$ & $145.07 \pm 4.66^{\mathrm{b}}$ & $32.97 \pm 0.73^{\mathrm{a}}$ & $69.33 \pm 0.59^{\mathrm{b}}$ & $143.78 \pm 6.24^{\mathrm{bc}}$ \\
\hline L.S.D $(\mathrm{P}<0.05)$ & 12.63 & 4.85 & 7.74 & 14.08 \\
\hline
\end{tabular}

Each value represents the mean $\pm \mathrm{SE}$.

The mean values in the same column with different superscript alphabets indicate significant differences $(\mathrm{P}<0.05)$ using LSD test.

* See Table (1).

nutritional deficiencies or imbalances of trace element such as chromium, iron, vanadium, copper and zinc led to elevation of cholesterol in serum or plasma (Ajayi, 2005). They reported that copper deficiency in rats produced hypercholesterolemia and an increase associated with LDL fraction. Also, Turbino-Ribeiro et al (2003) found that excess iron lowers plasma total-cholesterol and redistribution of cholesterol among various lipoprotein, resulted in an increase in HDL-C and reduction in LDL-C. Dieck et al (2003) reported that in liver of rats fed on diet deficient in zinc could be enhanced de novo synthesis of fatty acid in triglycerides and reduced degradation of stored fat. Also, dietary copper deficiency caused a similar mechanism in zinc deficiency.

In conclusions, results obtained in this study provide experimental evidence of the positive effect of trace elements such as $\mathrm{Zn}, \mathrm{Cu}$, and iron on antioxidant enzyme activity, like SOD, CAT, and GST. Our results demonstrated that there is an important relationship between these elements with the enzyme activity system against oxidative damage. These elements play a key role in cellular susceptibility to oxidative stress and its important factor for activity of antioxidant enzyme system.

\section{REFERENCES}

Aebi, H. (1984). Catalase in vitro. Methods Enzymol., 105 : 121 - 136.

Ajayi, O.B. (2005). Micronutriet changes in some tissues of copper deficient rats. Pakistan Journal of Nutrition, 4(2): 123-125.

Akcil, E.; F. Caylkli; M. Akiner and M. Kocak (2004). Trace element concentration and superoxide dismutase and catalase activities in benign and malignant larynx tumors. Biological Trace Element Research, 101: 193-201.

Asagba, S.O.; G.E. Eriyamremu; M.A. Adaikpoh and A. Ezeoma (2004). Levels of lipid peroxidation, superoxide dismutase, and $\mathrm{Na}^{+} / \mathrm{K}^{+}$ ATPase in some tissues of rats exposed to Nigerian-like diet and cadmium. Biological Trace Element Research, 100: 75-59.

Assmann, G. (1979). Dextran sulfate-Mg+2 precipitation procedure for high density lipoprotein cholesterol. Internist, 20: 559- 563.

Czeczot, H.; D. Scibior; M. Skrzycki and M. Podsiad (2006) Glutathione and GSH dependent enzymes in patients with liver cirrhosis and hepatocellular carcinoma. Acta Biochimica Pollonica, 53(1): 237-241.

Dieck, H.T.; F. Doring; H.P. Roth and H. Daniel (2003). Changes in rat hepatic gene expression 
in response to zinc deficiency as assessed by DNA arrays. J. Nutr., 133: 1004-1010.

Erdeve, O.; Z. Siklar; A.P. Kocaturyk; Y. Dallar and G.O. Kavas (2004). Antioxidant superoxide dismutase activity in obese children. Biological Trace Element Research, 98: 219-227.

Groff, J.L. and S.S. Gropper (2000). The fatsoluble vitamins: Ch 10 pp. 359- 370. Advanced Nutrition and Human metabolism. Library of Congress Cataloging in Publication Data, printed in the United States of America.

Guo, C.H.; G.S.W. Hsu; L.Y. Lin; Y.H. Wang; C.Y. Lin and M.S. Yeh (2004). Distribution patterns of trace metals and of lipid per oxidation in plasma and erythrocytes of rat exposed to aluminum. Biological Trace Element Research, 101: 61- 71.

Guven, A. (2005). Determination of reduced glutathione, glutathione S-transferase and selenium levels in goose liver cells with damage induced by carbon tetrachloride and ethanol. Turk. J. Vet. Anim. Sci., 29: 1233-1238.

Habig, W.H. and M.J. Pabst (1974). Glutathione S-transferase, the first enzymatic step in mercapturic acid formation. J. Biol. Chem., 249: 71307139.

Ibrahim, W.; U.S. Lee; C.C. Yeh; G. Bruckner and C.K. Chow (1997). Oxidative stress and antioxidant status in mouse liver: effect of dietary lipids, vitamin E and iron. J. Nutr. 127: 14011406.

Ken, C.F.; Y.F. Cheng; C.F. Chang; and C.T. Lin (2003). Copper/ zinc-superoxide dismutase from epinephelus malabaricus cDNA and enzyme property. J. Agric. Food Chem., 51: 5688- 5694.

Kocaturk, P.A.; G.O. Kavas; O. Erdeve and Z. Siklar (2004). Superoxide dismutase activity and zinc and copper concentrations in growth retardation. Biological Trace Element Research, 102: 51-59.

Kraus, A.; H.P. Roth and M. Kirchgessner (1997). Supplementation with vitamin C, Vitamin $\mathrm{E}$ or $\beta$-carotene influences osmotic fragility and oxidative damage of erythrocytes of zinc-deficient rats. J. Nut., 127: 1290-1296.

Kurtoglu, E.; A. Ugur; A.K. Baltaci and L. Undar (2003). Effect of iron supplementation on oxidative stress and antioxidant status in iron deficiency anemia. Biological Trace Element Research, 96: 117-123.

Lacy, F.O.; D.T. Connor and G.W. SchmidSchonbein (1998). Plasma hydrogen peroxide production in hypertensives and normotensive subjects at genetic risk of hypertension. J. Hypertension, 16: 291-303.

Metlzer, H.M.; M. Folmer; S. Wang; Q. Lie; A. Maggi and H.H. Mundal (1997). Supplementary selenium influences the response to fatty acidinduced oxidative-stress in humans. Biological Trace Element Research, 60: 51-60.

Miret, S.; A.T. McKie; M.P. Saiz; A. Bomford and M.T. Mitijavila (2003). IRP1 activity and expression are increased in the liver and the spleen of rats fed fish oil-rich diets and are related to oxidative stress. Journal of Nutrition, 133: 999. 1003.

Neefjes, V.M.E.; C.T.A. Evelo; L.G.M. Paars and C.E. Blanco (2007). Erythrocyte glutathione $\mathrm{S}$ transferase as a marker of oxidative stress at birth. Arch.Dis Child Neonatal Ed, 81: 130- 133. Nishikimi, M.; N.A. Roa and K. Yog (1972). The occurrence of superoxide anion in the reaction of reduced phenazine methosulphate and molecular oxygen. Biochem. Bioph. Res. Common., 46: 849 -854.

Ozcelik, D.; R. Ozaras; Z. Gurel; H. Uzun and S. Aydin (2003). Copper-mediated oxidative stress in rat liver. Biological Trace Element Research, 96: 209-215.

Pathak, A.; A.R. Mahmood and D. Dhawan (2004). Role of zinc on lipid peroxidation and antioxidative enzymes in intestines of ethanol-fed rats. Biological Trace Element Research, 103: 274-257.

Powell, S.R. (2000). The antioxidant properties of zinc. J. Nutri., 130: 1447s-1454s.

Prohaska, J.R. and A.A. Gybina (2004). Intercellular copper transport in mammals. Journal of Nutrition, 134: 1003 - 1006.

Rec, G. (1972). Determination of lactate dehydrogenase by enzymatic colourimetric methods. J. Clin. Chem. Biochem , 10: 182-187.

Reimers, E.G.; A.L. Lirola; R.M. Olivera; F.S. Fernandez; L.G. Martine; P.A. Gonzalez; J.J. Sanchez and A.M. Riera (2003). Effect of protein deficiency on liver trace elements and antioxidant activity in carbon tetracholoride-induced liver cirrhosis. Biological Trace Element Research, 93: 127-139.

Roeschlau, P.; E., Bernt and W.J., Gruber (1974). Enzymatic determination of totalcholesterol. Clin. Bioch., 12 : 403 - 410.

Roughead, Z.K.; L.K. Johnson and J.R. Hunt (1999). Dietary copper primarily affects antioxidant capacity and dietary iron mainly affects iron status in a surface response study of female rats 
fed varying concentrations of iron, zinc and copper. Journal of Nutrition, 129: 1368-1376.

Sato, M.; N. Kurihara; K. Moridaira; H. Sakamoto; J. Tamura; O. Wada and H. Yanagisawa (2003). Dietary $\mathrm{Zn}$ deficiency does not influence systemic blood pressure and vascular nitric oxide signaling in normotensive rats. Biological Trace Element Research, 91: 157171.

Snedecor, G.W. and W.G. Cochran (1980). Statistical Methods. $7^{\text {th }}$ Ed., Oxford and J.B.H. Publishing Com. London.

Snezana, B.P.; S.S. Zorica; P. Snezana; K. Jelena; S. Vesna and T.K. Dusan (2006). Antioxidative biomar keys and cancerogenesis. Jugoslov Med. Biochem., 25: 397-402.

Sun, J.Y.; M.Y. Jing; X.Y. Weng; Z.R. Fu; Z.R. Xu and J.F. Wang (2005). Effects of dietary zinc levels on the activities of enzymes, weights of organs, and the concentrations of zinc and copper in growing rats. Biological Trace Element Research, 107:135-165.
Trinder, P. (1969). Quantitative determination of serum triglycerides by the use of enzymes. Ann. Clin. Biochem., 6: $24-27$.

Turbino-Ribeiro, S.M.L.; M.E. Silva; D.A. Chianca; H. Paula; L.M. Cardoso; E. Colombari and M.L. Pedrosa (2003). Iron overload in hypercholesterolemic rats affects iron homeostasis and serum lipids but not blood pressure. J. Nutri., 133: 15-20.

Waschulewski, I.H. and R.A. Sunde (1988). Effect of dietary methionine on tissue selenium and glutathione peroxidase activity in rats given selenomethionine. J. Nutri., 60: 57-68.

Wieland, H. and D. Seidel (1983). A fully enzymatic colourimetric determination of LDLcholesterol in the serum . J. Lipid Res., 24: 904911.

Wu, C.C.; C.K. Li; S.J. Tsai and L.Y. Sheen (2004). Dially trisulfide modulates cell viability and the antioxidation and detoxification systems of rat primary hepatocytes. J. Nutri., 134: 724728. 